\title{
1 Temperature effect on U(VI) sorption onto Na-bentonite
}

2 Ziqian Yang ${ }^{a}$, Lei Huang ${ }^{a}$, Zhijun Guo ${ }^{a}{ }^{*}$, Gilles Montavon $^{b}$, Wangsuo Wu $^{a}$

3 ' ${ }^{\mathrm{a}}$ Radiochemistry Lab, School of Nuclear Science and Technology, Lanzhou

4 University, 730000, Lanzhou, China

5 bubatech Laboratory, CNRS/In2P3/Ecole des Mines de Nantes/Université de

6 Nantes, 4 rue Alfred Kastler, BP 20722, 44307 Nantes, France

Sorption / U(VI ) / Na-bentonite / Temperature effect / Surface complexation model

\section{Summary}

9 U(VI) sorption on a purified Na-bentonite was investigated from $298 \pm 2$ to $353 \pm 2 \mathrm{~K}$ by using a batch experimental method as a function of $\mathrm{pH}, \mathrm{U}(\mathrm{VI})$ concentration, carbonate concentration and solid-to-liquid ratio $(\mathrm{m} / \mathrm{V})$. The data at $298 \pm 2 \mathrm{~K}$ could be well described by a surface complexation model (SCM) with a complex located on layer sites $\left(\mathrm{X}_{2} \mathrm{UO}_{2}\right)$ and three complexes located on edge sites $\left(\equiv \mathrm{SOUO}_{2}{ }^{+}\right.$,

$14 \equiv \mathrm{SO}\left(\mathrm{UO}_{2}\right)_{3}(\mathrm{OH})_{5}$, and $\left.\equiv \mathrm{SO}\left(\mathrm{UO}_{2}\right)_{3}(\mathrm{OH})_{7}{ }^{2-}\right)$. The intrinsic equilibrium constants $\left(K^{\mathrm{int}}\right)$ of the surface reactions at $333 \pm 2 \mathrm{~K}$ and $353 \pm 2 \mathrm{~K}$ were obtained by fitting $\mathrm{U}(\mathrm{VI})$ 16 sorption curves versus $\mathrm{pH}$ on the Na-bentonite. The model enables U(VI) sorption in the presence of carbonate $\left(P_{\mathrm{CO}_{2}}=10^{-3.58}\right.$ atm) to be described without considering any ternary surface complexes involving carbonate, except for underestimation around

$19 \mathrm{pH} 7(6<\mathrm{pH}<7.5)$. The standard enthalpy changes $\left(\Delta_{r} H_{m}^{\theta}\right)$ of the surface reactions 20 were evaluated from the $K^{\text {int }}$ values obtained at three temperatures $(298 \pm 2,333 \pm 2$

\footnotetext{
* Corresponding author, E-mail address: guozhj@1zu.edu.cn (Z.GUO)
} 
1 and $353 \pm 2 \mathrm{~K}$ ) via the van't Hoff equation. The proposed SCM and $\Delta_{r} H_{m}^{\theta}$ of the

2 surface reactions enable U(VI) sorption on the Na-bentonite at other temperatures to

3 be predicted.

\section{$4 \quad$ 1. Introduction}

5 Because of its excellent physicochemical properties such as high specific surface

6 area, large cation exchange and sorption capacity, and good swelling and sealing

7 nature, bentonite has been considered as a backfilling material for deep geological

8 repository of high-level radioactive waste in many countries. Uranium(VI) is an

9 important contaminant to be considered in nuclear waste management and the

10 sorption of $\mathrm{U}(\mathrm{VI})$ on bentonite/montmorillonite has received special attentions [1-9].

11 Different surface complexation models (SCMs) have been proposed to quantitatively

12 describe macroscopic sorption of $\mathrm{U}(\mathrm{VI})$ on bentonite/montmorillonite using two

13 main approaches. The first one treats montmorillonite as an aggregate of

14 fixed-charge sites and edge sites analogous to gibbsite and silica [1]. The surface

15 complexation constants for uranyl binding to gibbsite and silica were used for the

16 edge sites. Different electrostatic models were chosen, for example, a triple-layer

17 model was used by Turner et al. [2], whereas a constant capacitance model was used

18 by Kowal-Fouchard et al [6]. Another approach is to consider montmorillonite as a

19 specific sorbent. The capacity of layer sites is estimated by CEC measurement, while

20 the densities of edge sites as well as the protonation and deprotonation constants are

21 obtained by fitting the acid-base titration data at variable ionic strengths [10-14]. 
2 high-level radioactive waste may be higher than the ambient temperature and vary

3 with time because of radionuclide decay [15-17]. However, most sorption data

4 reported up to date were collected at ambient temperature and studies on temperature

5 effect are still lacking [15]. In this paper, U(VI) sorption on a purified Na-bentonite at

$6298 \pm 2 \mathrm{~K}$ was studied as a function of $\mathrm{pH}, \mathrm{U}(\mathrm{VI})$ concentration, solid-to-liquid ratio

$7(m / V)$ and carbonate concentration by batch sorption experiments, and a SCM was

8 constructed based on the sorption data collected at $298 \pm 2 \mathrm{~K}$. Then, U(VI) sorption

9 curves versus $\mathrm{pH}$ on the Na-bentonite at elevated temperatures $(333 \pm 2 \mathrm{~K}$ and $353 \pm 2 \mathrm{~K})$

10 were collected and the proposed SCM was fitted to these sorption data at elevated

11 temperatures, respectively, to obtain the intrinsic equilibrium constants $\left(K^{\text {int }}\right)$ of the

12 surface complexation reactions at elevated temperatures. Finally, the $K^{\text {int }}$ at three 13 temperatures $(298 \pm 2,333 \pm 2$ and $353 \pm 2 \mathrm{~K})$ were used to assess $\Delta_{r} H_{m}^{\theta}$ of the surface 14 complexation reactions via the van't Hoff equation.

\section{Experimental}

\subsection{Materials}

The Na-bentonite used in this work was obtained from Jinchuan Bentonite Company

18 (Jinchuan, Gansu Province, China). The protocols of purification and characterization of the purified Na-bentonite have been described in our previous paper [14]. The purified Na-bentonite is mainly composed of $12 \mathrm{wt} . \%$ quartz and 88

21 wt.\% montmorillonite with a calculated structural formula of $\left[\mathrm{Si}(\mathrm{IV})_{8}\right]\left(\mathrm{Al}(\mathrm{III})_{3.19}\right.$, 
$\left.1 \quad \mathrm{Fe}(\mathrm{III})_{0.29}, \mathrm{Fe}(\mathrm{II})_{0.38}, \mathrm{Mg}(\mathrm{II})_{0.14}\right) \mathrm{O}_{20}(\mathrm{OH})_{4}\left(\mathrm{Ca}(\mathrm{II})_{0.023}, \mathrm{Na}(\mathrm{I})_{0.35}, \mathrm{~K}(\mathrm{I})_{0.127}\right)$. The CEC was

2 experimentally found to be $623 \pm 12 \mathrm{meq} / \mathrm{kg}$ and is consistent with the value

3 calculated according to the structural formula. The specific surface area obtained by

4 B.E.T. analyses using $\mathrm{N}_{2}$ was found to be $53.6 \mathrm{~m}^{2} / g$. A uranium(VI) stock solution

5 was prepared from $\mathrm{UO}_{2}\left(\mathrm{NO}_{3}\right)_{2} \cdot 6 \mathrm{H}_{2} \mathrm{O}$ (A.R. grade, made in China). All other

6 chemicals used were at least analytical grade. All solutions were prepared with

7 deionized water $(18 \mathrm{M} \Omega / \mathrm{cm})$.

8

\subsection{Sorption}

Sorption experiments were carried out in a nitrogen atmosphere glove box, except for the sorption in the presence of carbonate. The Na-bentonite was dispersed with $\mathrm{NaCl}$ solution $(0.1 \mathrm{~mol} / \mathrm{L})$ in polyethylene tubes and the $\mathrm{pH}$ of the suspension was adjusted by adding small amounts of $\mathrm{HCl}$ or $\mathrm{NaOH}$ solutions. Proper amounts of the uranium stock solution were added and the suspension was shaken for 2 days before analysis. The elevated temperature was controlled by a water bath. Our prior sorption experiments demonstrated that sorption steady state can be reached within 2 days. The $\mathrm{pH}$ of the suspension was recorded at the experimental temperature on a Metrohm $781 \mathrm{pH} /$ ion Meter with a combined glass electrode (Metrohm No.6.0234.100) which was calibrated with three standard buffers. Phase separation was carried out by centrifugation at $18000 \mathrm{~g}$ for $30 \mathrm{~min}$. The concentration of U(VI) in the aqueous phase was analyzed by spectrophotometry at a wavelength of $652 \mathrm{~nm}$ by using U(VI) and Arsenazo-III complex. The relative errors of spectrophotometric measurements were less than $5 \%$. The sorption on the tube walls was negligible. The 
1 amount of $\mathrm{U}(\mathrm{VI})$ sorbed $(q, \mathrm{~mol} / \mathrm{g})$ was calculated by the difference of the initial and

2 final concentrations in the aqueous phase $\left(C_{0}\right.$ and $C_{\text {eq }}$, respectively, mol/L):

3

4 where $V(\mathrm{~L})$ is the volume of aqueous phase and $m(\mathrm{~g})$ the mass of Na-bentonite. The $5 \quad$ sorption percentage of U(VI) was calculated by

$$
\text { Sorption }(\%)=\frac{C_{0}-C_{e q}}{C_{0}} \times 100
$$

7 The sorption experiment in the presence of carbonate was performed at the normal 8 atmospheric condition $\left(P_{\mathrm{CO}_{2}}=10^{-3.58}\right.$ atm). The $\mathrm{pH}$ of Na-bentonite suspension was

9 adjusted with $\mathrm{HCl}$ or $\mathrm{NaHCO}_{3} / \mathrm{Na}_{2} \mathrm{CO}_{3}$ solutions. The tubes were opened regularly during sorption until the $\mathrm{pH}$ values were stable. The analytical methods were the

11 same as described above.

\subsection{Modeling}

The sorption of U(VI) was interpreted by a double layer model (DLM), based on the acid-base chemistry of the Na-bentonite which has been reported in detail in our previous paper [14]. Two types of sorption sites were considered: layer sites $\left(\mathrm{X}^{-}\right)$and edge sites. Both aluminol $(\equiv \mathrm{SOH})$ and silanol $(\equiv \mathrm{YOH})$ edge sites were included for the acid-base chemistry of the Na-bentonite. The capacities of the sites as well as the constants of protonation and deprotonation were summarized in Table 1. The code PHREEQC [18] was used for modeling calculations. Activity correction of the aqueous species was made by the Davies equation. U(VI) thermodynamic data used 
1 in modeling were taken from the NEA (Nuclear Energy Agency) database [19],

2 except for those of $\mathrm{UO}_{2}(\mathrm{OH})_{2}(\mathrm{aq})$ which were taken from the Nagra/PSI Chemical

3 Thermodynamic Data Base [20]; in the NEA database, only a maximum limit of the

4 equilibrium constant was given for this species. The U(VI) thermodynamic data used

$5 \quad$ in the modeling are listed in Table 2.

\section{Results and Discussion}

3.1 U(VI) sorption on Na-bentonite at $T=298 \pm 2 \mathrm{~K}$

Sorption curves of $\mathrm{U}(\mathrm{VI})$ versus $\mathrm{pH}$ on the Na-bentonite at $298 \pm 2 \mathrm{~K}$ and different

9 U(VI) concentrations $\left(4.01 \times 10^{-5}\right.$ and $\left.8.02 \times 10^{-5} \mathrm{~mol} / \mathrm{L}\right)$ are presented in Fig. 1 . The sorption of $\mathrm{U}(\mathrm{VI})$ on Na-bentonite is strongly $\mathrm{pH}$-dependent; the sorption percentage

11 of $\mathrm{U}(\mathrm{VI})$ increases slightly up to $\mathrm{pH} 4$ and then increases significantly in the $\mathrm{pH}$ range of $4-8$. This is consistent with previous observations of U(VI) sorption on montmorillonite/bentonite $[2,6]$. The sorption curve of $\mathrm{U}(\mathrm{VI})$ versus $\mathrm{pH}$ at $8.02 \times 10^{-5}$ $\mathrm{mol} / \mathrm{L}$ is shifted somewhat to higher $\mathrm{pH}$ in comparison with that at $4.01 \times 10^{-5} \mathrm{~mol} / \mathrm{L}$, indicating that $\mathrm{U}(\mathrm{VI})$ sorption percentage decreases with $\mathrm{U}(\mathrm{VI})$ concentration at a given $\mathrm{pH}$. The inflection of sorption curves of $\mathrm{U}(\mathrm{VI})$ against $\mathrm{pH}$ results from a

17 variation of sorption mechanisms. In the low $\mathrm{pH}$ range, U(VI) sorption on bentonite/montmorillonite has been interpreted by cation exchange on layer sites, whereas $\mathrm{U}(\mathrm{VI})$ surface complexation reactions on edge sites occur at $\mathrm{pH}>4[3,6$, 11]. The two types of U(VI) surface species have been supported by spectroscopic 21 studies. Extended X-ray absorption fine structure (EXAFS) studies on U(VI) 
1 sorption on montmorillonite have suggested that U(VI) adsorption on

2 montmorillonite is most likely through an outer-sphere cation-exchange mechanism

3 at low $\mathrm{pH}$, whereas a transition to an inner-sphere surface complexation mechanism

4 occurs at near neutral $\mathrm{pH}[7-8]$. However, the detailed nature of the surface species

5 formed at the edge sites can not be simply deduced from these spectroscopic studies

6 [3]. Surface complexes are usually supposed based on analogous speciation in the

7 aqueous phase $[3,11]$. U(VI) speciation in the aqueous phase strongly depends on

8 experimental conditions such as $\mathrm{pH}, \mathrm{U}(\mathrm{VI})$ concentration, and the presence of

9 ligands [21]. For comparison, both U(VI) speciations in the absence and presence of

$10 \mathrm{CO}_{2}\left(P_{\mathrm{CO}_{2}}=10^{-3.58} \mathrm{~atm}\right)$ at $C_{U(V I)}^{0}=4.0 \times 10^{-5} \mathrm{~mol} / \mathrm{L}$ and $I=0.1 \mathrm{~mol} / \mathrm{L} \mathrm{NaCl}$ are

11 shown in Fig. 2. $\mathrm{UO}_{2}{ }^{2+}$ is the dominant species at $\mathrm{pH} \leq 5$ in both $\mathrm{CO}_{2}$ conditions and

$12 \mathrm{U}(\mathrm{VI})$ polynuclear hydrolysis products, $\left(\mathrm{UO}_{2}\right)_{3}(\mathrm{OH})_{5}{ }^{+}$and $\left(\mathrm{UO}_{2}\right)_{3}(\mathrm{OH})_{7}{ }^{-}$, become

13 major species in the high $\mathrm{pH}$ range in the absence of $\mathrm{CO}_{2}$. Therefore, $\mathrm{UO}_{2}{ }^{2+}$,

$14\left(\mathrm{UO}_{2}\right)_{3}(\mathrm{OH})_{5}{ }^{+}$and $\left(\mathrm{UO}_{2}\right)_{3}(\mathrm{OH})_{7}{ }^{-}$are considered as the $\mathrm{U}(\mathrm{VI})$ species sorbed at the

15 surface in the present study.

16 The first surface reaction considered in the modeling is the binding of $\mathrm{UO}_{2}{ }^{2+}$ on the 17 layer sites $\left(\mathrm{X}^{-}\right)$:

$$
2 \mathrm{XNa}+\mathrm{UO}_{2}^{2+} \rightleftharpoons \mathrm{X}_{2} \mathrm{UO}_{2}+2 \mathrm{Na}^{+}
$$

$$
K_{1}=\frac{\left[\mathrm{X}_{2} \mathrm{UO}_{2}\right]\left[\mathrm{Na}^{+}\right]^{2}}{[\mathrm{XNa}]^{2}\left[\mathrm{UO}_{2}^{2+}\right]} \cdot \frac{\gamma_{\mathrm{Na}^{+}}^{2}}{\gamma_{\mathrm{UO}_{2}^{2+}}}
$$

As expected, $\mathrm{U}(\mathrm{VI})$ sorption in the low $\mathrm{pH}$ range can be described by reaction (3),

21 other surface reactions on edge sites must be considered to interpret the sharp 
1 increase in the high $\mathrm{pH}$ range. Inner-sphere surface complexes of $\mathrm{UO}_{2}{ }^{2+}$ and

$2\left(\mathrm{UO}_{2}\right)_{3}(\mathrm{OH})_{5}{ }^{+}$on both aluminol and silanol edge sites are commonly considered [1-3,

3 6,9]. Since aluminol sites are much more reactive than silanol sites $[4,16]$ and

4 cations primarily sorb on octahedral sites such as $\mathrm{Al}(\mathrm{O}, \mathrm{OH})_{6}$ and $\mathrm{Fe}(\mathrm{O}, \mathrm{OH})_{6}[8]$,

5 only surface complexation reactions on aluminol sites $(\equiv \mathrm{SOH})$ were considered in

6 the present paper. Similar modeling strategies have been used to interpret Eu(III)

7 sorption on montmorillonite/bentonite $[14,16]$. Surface complexation reactions of

$8 \quad \mathrm{UO}_{2}{ }^{2+},\left(\mathrm{UO}_{2}\right)_{3}(\mathrm{OH})_{5}{ }^{+}$and $\left(\mathrm{UO}_{2}\right)_{3}(\mathrm{OH})_{7}{ }^{-}$on $\equiv \mathrm{SOH}$ can be respectively expressed as:

9

10

$$
\equiv \mathrm{SOH}+\mathrm{UO}_{2}^{2+} \rightleftharpoons \mathrm{SOUO}_{2}^{+}+\mathrm{H}^{+}
$$$$
\equiv \mathrm{SOH}+3 \mathrm{UO}_{2}{ }^{2+}+5 \mathrm{H}_{2} \mathrm{O} \rightleftharpoons \equiv \mathrm{SO}\left(\mathrm{UO}_{2}\right)_{3}(\mathrm{OH})_{5}+6 \mathrm{H}^{+}
$$$$
\equiv \mathrm{SOH}+3 \mathrm{UO}_{2}{ }^{2+}+7 \mathrm{H}_{2} \mathrm{O} \rightleftharpoons \equiv \mathrm{SO}\left(\mathrm{UO}_{2}\right)_{3}(\mathrm{OH})_{7}{ }^{2-}+8 \mathrm{H}^{+}
$$

The corresponding intrinsic equilibrium constants of reactions (5) - (7) are as follows:

$$
\begin{aligned}
& K_{2}^{\mathrm{int}}=\frac{\left[\equiv \mathrm{SOUO}{ }_{2}^{+}\right]\left[\mathrm{H}^{+}\right]}{[\equiv \mathrm{SOH}]\left[\mathrm{UO}_{2}^{2+}\right]} \cdot \frac{\gamma_{\mathrm{H}^{+}}}{\gamma_{\mathrm{UO}_{2}{ }^{2+}}} \exp (F \Psi / R T) \\
& K_{3}=\frac{\left[\equiv \mathrm{SO}\left(\mathrm{UO}{ }_{2}\right)_{3}(\mathrm{OH})_{5}\right]\left[\mathrm{H}^{+}\right]^{6}}{[\equiv \mathrm{SOH}]\left[\mathrm{UO}_{2}^{2+}\right]^{3}} \cdot \frac{\gamma_{\mathrm{H}^{+}}^{6}}{\gamma_{\mathrm{UO}_{2}^{3+}}^{3}} \\
& K_{4}^{\text {int }}=\frac{\left[\equiv \mathrm{SO}\left(\mathrm{UO}{ }_{2}\right)_{3}(\mathrm{OH})_{7}^{2-}\right]\left[\mathrm{H}^{+}\right]^{8}}{[\equiv \mathrm{SOH}]\left[\mathrm{UO}_{2}^{2+}\right]^{3}} \cdot \frac{\gamma_{\mathrm{H}^{+}}^{8}}{\gamma_{\mathrm{UO}_{2}^{2+}}^{3}} \exp (-2 F \Psi / R T)
\end{aligned}
$$

A stepwise fitting approach [11] was used to evaluate the equilibrium constants of the surface reactions by fitting U(VI) sorption curves versus pH at $298 \pm 2 \mathrm{~K}$ (Fig. 1). Surface reactions (3) and (5)-(7) were sequentially considered to describe the 
1 sorption curves of $\mathrm{U}(\mathrm{VI})$ against $\mathrm{pH}$ from low to high $\mathrm{pH}$ and finally the equilibrium

2 constants at $298 \pm 2 \mathrm{~K}$ were estimated (Table 3 ). The calculated results are shown as

3 lines in Fig. 1.

4 The model was then used as a predictive tool to describe experimental data measured

5 as a function of $\mathrm{U}(\mathrm{VI})$ concentration and $m / V$. Two U(VI) sorption isotherms at

$6298 \pm 2 \mathrm{~K}$ and different $\mathrm{pH}(4.78 \pm 0.10$ and $5.76 \pm 0.10)$ were collected (Fig. 3). The

7 two isotherms are almost parallel and are well described by the model. Moreover,

$8 \mathrm{U}(\mathrm{VI})$ sorption dependence on $m / V$ was carried out at $T=298 \pm 2 \mathrm{~K}, C_{\mathrm{U}(\mathrm{VI})}^{0}=$

$98.02 \times 10^{-5} \mathrm{~mol} / \mathrm{L}, \mathrm{pH} 5.00 \pm 0.10$ and $I=0.1 \mathrm{~mol} / \mathrm{L} \mathrm{NaCl}$. As seen in Fig. 4, the sorption percentage of $\mathrm{U}(\mathrm{VI})$ increases with $m / \mathrm{V}$, due to the increase of available

11 sites, which is well reproduced by the model. The good interpretation for the U(VI)

12 sorption isotherms and the sorption dependence on $m / V$ imply that the proposed 13 model is reasonable.

\subsection{U(VI) sorption at $P_{\mathrm{CO}_{2}}=10^{-3.58} \mathrm{~atm}$ and $T=298 \pm 2 \mathrm{~K}$}

Carbonate is an extensive ligand in the environment and the partial pressure of $\mathrm{CO}_{2}$ in aquifers commonly reaches values of $1-5 \%$ [22]. Since carbonate has a strong binding affinity for uranyl, the effect of carbonate on U(VI) sorption is of importance. A sorption curve of $\mathrm{U}(\mathrm{VI})$ versus $\mathrm{pH}$ on the $\mathrm{Na}$-bentonite in the presence of $\mathrm{CO}_{2}$ $\left(P_{\mathrm{CO}_{2}}=10^{-3.58} \mathrm{~atm}\right)$ was also collected in this study to evaluate the effect of carbonate and to test the performance of the proposed model. For comparison, U(VI) sorption data in the absence and presence of $\mathrm{CO}_{2}$ as a function of $\mathrm{pH}$ are simultaneously shown in Fig. 5. At $\mathrm{pH}<6.0$, the two series of sorption data are identical, suggesting that in the low $\mathrm{pH}$ range the presence of $\mathrm{CO}_{2}$ has a negligible influence on $\mathrm{U}(\mathrm{VI})$ sorption. At $\mathrm{pH}$ around $7(6<\mathrm{pH}<7.5), \mathrm{U}(\mathrm{VI})$ sorption increases somewhat in the presence of 
$1 \mathrm{CO}_{2}$, whereas at $\mathrm{pH}>7.5 \mathrm{U}(\mathrm{VI})$ sorption decreases compared to that in the absence of

$2 \mathrm{CO}_{2}$. Since the concentration of carbonate in the aqueous phase increases significantly

3 with increasing $\mathrm{pH}$ at a constant $\mathrm{CO}_{2}$ partial pressure, the difference between the

4 sorption curves of $\mathrm{U}(\mathrm{VI})$ versus $\mathrm{pH}$ in the absence and presence of $\mathrm{CO}_{2}$ may be related to an effect of carbonate on U(VI) speciation in the aqueous phase [3, 9]. As seen in Fig. 2, in the presence of $\mathrm{CO}_{2}\left(P_{\mathrm{CO}_{2}}=10^{-3.58}\right.$ atm), the importance of $\left(\mathrm{UO}_{2}\right)_{3}(\mathrm{OH})_{5}{ }^{+}$in the alkaline $\mathrm{pH}$ range is to some extent decreased and the content of $\left(\mathrm{UO}_{2}\right)_{3}(\mathrm{OH})_{7}{ }^{-}$is completely suppressed, due to the formation of $\left(\mathrm{UO}_{2}\right)_{2} \mathrm{CO}_{3}(\mathrm{OH})_{3}{ }^{-}$, $\mathrm{UO}_{2}\left(\mathrm{CO}_{3}\right)_{2}{ }^{2-}$ and $\mathrm{UO}_{2}\left(\mathrm{CO}_{3}\right)_{3}{ }^{4-}$. Considering that the montmorillonite surface at a $\mathrm{pH}$ near 7 and in alkaline $\mathrm{pH}$ region is negatively charged $[13,14]$, the affinity of high negatively charged uranyl complexes of carbonate, $\mathrm{UO}_{2}\left(\mathrm{CO}_{3}\right)_{2}{ }^{2-}$ and $\mathrm{UO}_{2}\left(\mathrm{CO}_{3}\right)_{3}{ }^{4-}$, for the surface may be weaker than the U(VI) hydrolysis products, $\left(\mathrm{UO}_{2}\right)_{3}(\mathrm{OH})_{5}{ }^{+}$and $\left(\mathrm{UO}_{2}\right)_{3}(\mathrm{OH})_{7}^{-}$, because of higher electrostatic repulsion. Thus, the sorption of U(VI) decreases sharply in the presence of $\mathrm{CO}_{2}$ at $\mathrm{pH}>7.5$ compared to that in the absence of $\mathrm{CO}_{2}$. This is in agreement with the carbonate effect on $\mathrm{U}(\mathrm{VI})$ sorption on other minerals such as ferrihydrite [23] and hematite [24]. A similar decrease of Eu(III) sorption on the Na-bentonite was also observed in the presence of $\mathrm{CO}_{2}$ [14]. The higher $\mathrm{U}(\mathrm{VI})$ sorption around $\mathrm{pH} 7(6<\mathrm{pH}<7.5)$ in the presence of $\mathrm{CO}_{2}$ may be due to the binding of $\left(\mathrm{UO}_{2}\right)_{2} \mathrm{CO}_{3}(\mathrm{OH})_{3}{ }^{-}$on the surface because $\left(\mathrm{UO}_{2}\right)_{2} \mathrm{CO}_{3}(\mathrm{OH})_{3}{ }^{-}$is the dominant $\mathrm{U}(\mathrm{VI})$ aqueous species around $\mathrm{pH} 7$ in additional to $\left(\mathrm{UO}_{2}\right)_{3}(\mathrm{OH})_{5}{ }^{+}$.

As a first estimation, the proposed model without considering any ternary surface complexes of carbonate was used to predict the U(VI) sorption curve versus $\mathrm{pH}$ in the presence of $\mathrm{CO}_{2}$ at $P_{\mathrm{CO}_{2}}=10^{-3.58} \mathrm{~atm}, C_{\mathrm{U}(\mathrm{VI})}^{0}=8.02 \times 10^{-5} \mathrm{~mol} / \mathrm{L}, I=0.1 \mathrm{M} \mathrm{NaCl}$, and $m / V=1 \mathrm{~g} / \mathrm{L}$. As can be seen in Fig. 5, the model could readily interpret the identical sorption at $\mathrm{pH}<6$ and the lower sorption at $\mathrm{pH}>7.5$. However, it underestimates $\mathrm{U}(\mathrm{VI})$ sorption around $\mathrm{pH} 7(6.0<\mathrm{pH}<7.5)$. To improve the agreement, the binding of $\left(\mathrm{UO}_{2}\right)_{2} \mathrm{CO}_{3}(\mathrm{OH})_{3}{ }^{-}$on $\equiv \mathrm{SOH}$ was considered: 


$$
1 \equiv \mathrm{SOH}+2 \mathrm{UO}_{2}{ }^{2+}+3 \mathrm{H}_{2} \mathrm{O}+\mathrm{CO}_{3}{ }^{2-} \rightleftharpoons \equiv \mathrm{SO}\left(\mathrm{UO}_{2}\right)_{2} \mathrm{CO}_{3}(\mathrm{OH})_{3}{ }^{2-}+4 \mathrm{H}^{+}
$$

2 Although ternary surface complexes of U(VI) and carbonate on montmorillonite

3 have been suggested by a recent EXAFS study [8], modeling exercises indicated that

4 reaction (11) could not improve the fitting goodness for the sorption curve of U(VI)

5 versus $\mathrm{pH}$ in the presence of $\mathrm{CO}_{2}$ (Fig. 5). The reason is not clear and further 6 investigation is still needed.

\subsection{Effect of temperature on U(VI) sorption onto Na-bentonite}

The influence of temperature on chemical reactions can be described by the van't

9 Hoff equation:

$$
\log K^{\theta}=-\frac{\Delta_{r} H_{m}^{\theta}}{2.303 R} \cdot \frac{1}{T}+\frac{\Delta_{r} S_{m}^{\theta}}{2.303 R}
$$

11 where $K^{\theta}$ is the standard equilibrium constant of the reaction at absolute temperature $T, R$ the gas constant, $\Delta_{r} H_{m}^{\theta}$ the standard enthalpy change and $\Delta_{r} S_{m}^{\theta}$ the standard entropy change. When $\Delta_{r} H_{m}^{\theta}$ and $\Delta_{r} S_{m}^{\theta}$ are considered as constants with temperature, $\Delta_{r} H_{m}^{\theta}$ can be evaluated by the slope of $\log K^{\theta}$ against $1 / T$ plot. The relationship between $K_{1}^{\theta}$ at $T_{1}$ and $K_{2}^{\theta}$ at $T_{2}$ can be described by

$$
\ln \left(\frac{K_{2}^{\theta}}{K_{1}^{\theta}}\right)=\frac{-\Delta_{r} H_{m}^{\theta}}{R}\left(\frac{1}{T_{2}}-\frac{1}{T_{1}}\right)
$$

17 With a known $\Delta_{r} H_{m}^{\theta}$ and $K_{1}^{\theta}$ at $T_{1}$, Eq. (13) can be used to estimate $K_{2}^{\theta}$ at any other $T_{2}$. Considering the temporal and spatial variation of temperature in the near

19 field of deep geological repository for high-level radioactive waste, $\Delta_{r} H_{m}^{\theta}$ of 
1 surface reactions involving radionuclide sorption on back-filling materials (e.g.

2 bentonite) are necessary for nuclear waste management [15-17]. In this study, U(VI)

3 sorption curves versus $\mathrm{pH}$ on the Na-bentonite measured at $C_{\mathrm{U}(\mathrm{VI})}^{0}=8.02 \times 10^{-5}$

$4 \mathrm{~mol} / \mathrm{L}, I=0.1 \mathrm{~mol} / \mathrm{L} \mathrm{NaCl}, m / V=1 \mathrm{~g} / \mathrm{L}$ and three temperatures $(298 \pm 2,333 \pm 2$ and

$5353 \pm 2 \mathrm{~K}$ ) were collected to evaluate the $\Delta_{r} H_{m}^{\theta}$ of surface reactions in the proposed

6 model. As shown in Fig. 6, U(VI) sorption on the Na-bentonite does not vary with

7 temperature at $\mathrm{pH}<3.5$, suggesting that the temperature effect on $\mathrm{U}(\mathrm{VI})$ binding to

8 the layer sites is negligible. Above $\mathrm{pH} 3.5, \mathrm{U}(\mathrm{VI})$ sorption on the solid phase

9 increases with increasing temperature, indicating that U(VI) surface complexation

10 reactions on edge sites are endothermic. Similar observations have been reported for

$11 \mathrm{Eu}(\mathrm{III}) / \mathrm{montmorillonite} \mathrm{and} \mathrm{Eu}(\mathrm{III}) /$ kaolinite sorption systems [16].

12 In principle, the equilibrium constants deduced in this study could be considered as

13 intrinsic constants, although the electrostatic correction for clays is still a matter of

14 discussion $[11,16,25]$. To assess $\Delta_{r} H_{m}^{\theta}$ of the surface reactions in the model, $K^{\text {int }}$

15 at $298 \pm 2,333 \pm 2$ and $353 \pm 2 \mathrm{~K}$ should be first obtained. The $K^{\text {int }}$ of surface reactions

16 at $333 \pm 2$ and $353 \pm 2 \mathrm{~K}$ were obtained by fitting the SCM to the sorption data at the

17 respective temperatures. The prerequisite information for these fittings is that all

$18 \Delta_{r} H_{m}^{\theta}$ of the related reactions, either in the aqueous phase or at the surface, should

19 be known, because both the standard equilibrium constants at $298.15 \mathrm{~K}$ and the

$20 \Delta_{r} H_{m}^{\theta}$ of these reactions are needed to calculate the equilibration constants at

21 elevated temperatures. The $\Delta_{r} H_{m}^{\theta}$ of some $\mathrm{U}(\mathrm{VI})$ hydrolysis reactions were not

22 available in both the NEA [19] and the Nagra/PSI databases [20], and were assumed 
1 to be 0 in calculations. This implies that the standard equilibrium constants at 298.15

$2 \mathrm{~K}$ were used in the whole temperature range. The $\Delta_{r} H_{m}^{\theta}$ of surface reactions

3 responsible for the acid-base chemistry of the Na-bentonite were also assumed to be

4 0. This assumption is reasonable according to the work by Duc et al. [17], which

5 indicated that the protonation and deprotonation reactions on edge sites of

6 montmorillonite are not significantly temperature-dependent. Moreover, according to

7 the negligible temperature effect upon U(VI) sorption at low pH (Fig. 6), the $\Delta_{r} H_{m}^{\theta}$

8 of $\mathrm{UO}_{2}{ }^{2+}$ binding on the layer sites was directly assumed to be 0 . Similar

9 assumptions have been made for $\mathrm{Eu}(\mathrm{III})$ sorption on montmorillonite and kaolinite

10 [16]. Based on the above assumptions, the $K^{\text {int }}$ of surface reactions (5) - (7) at $333 \pm 2$

11 and $353 \pm 2 \mathrm{~K}$ were estimated by using the geochemical modeling code PHREEQC

12 [18]. The obtained $K^{\text {int }}$ values are listed in Table 3 and the calculated results by the 13 model are presented as lines in Fig. 6. The $K^{\text {int }}$ values of reactions (5)-(7) increase 14 with increasing temperature.

15 According to the van't Hoff equation, $\log K^{\text {int }}$ values are plotted against $1 / T$, and the 16 plots for reactions (5) - (7) are illustrated in Fig. 7. Good correlation coefficients are 17 obtained in all cases, which may imply that the assumptions made above are to some 18 extent reasonable. From the slopes of these plots, $\Delta_{r} H_{m}^{\theta}$ of reactions (5)-(7) are 19 calculated and listed also in Table 3. The positive $\Delta_{r} H_{m}^{\theta}$ indicate that the surface 20 complexation reactions (5) - (7) are endothermic processes, which are consistent 21 with the experimental observations. In principle, the proposed SCM and $\Delta_{r} H_{m}^{\theta}$ of 22 the surface reactions may enable U(VI) sorption on the Na-bentonite at other 
1 temperatures to be predicted. Finally, it should be pointed out that complementary

$2 \Delta_{r} H_{m}^{\theta}$ of $\mathrm{U}(\mathrm{VI})$ aqueous reactions which are not listed in the databases are

3 necessary to carry out reliable predictions of $\mathrm{U}(\mathrm{VI})$ sorption at variable temperatures.

\section{4. Conclusions}

5 Based on the experimental and modeling results in the present study, the following

6 conclusions can be made:

7 (1) U(VI) sorption on the purified Na-bentonite at different temperatures $(298 \pm 2$,

$8 \quad 333 \pm 2$ and $353 \pm 2 \mathrm{~K}$ ) could be quantitatively described by the SCM with a complex

9 on layer sites $\left(\mathrm{X}_{2} \mathrm{UO}_{2}\right)$ and three complexes on edge sites $\left(\equiv \mathrm{SOUO}_{2}{ }^{+}\right.$,

$10 \equiv \mathrm{SO}\left(\mathrm{UO}_{2}\right)_{3}(\mathrm{OH})_{5}$, and $\left.\equiv \mathrm{SO}\left(\mathrm{UO}_{2}\right)_{3}(\mathrm{OH})_{7}{ }^{2-}\right)$. It seems that the nature of the surface

11 species is governed by U(VI) speciation in solution.

12 (2) $\mathrm{U}(\mathrm{VI})$ sorption on the Na-bentonite in the presence of $\mathrm{CO}_{2}\left(P_{\mathrm{CO}_{2}}=10^{-3.58} \mathrm{~atm}\right)$ is 13 identical to that in the absence of $\mathrm{CO}_{2}$ at $\mathrm{pH}<6$. The $\mathrm{SCM}$ could interpret the 14 identical sorption at $\mathrm{pH}<6$ and the lower sorption at $\mathrm{pH}>7.5$. However, it 15 underestimates to some extent the sorption of $\mathrm{U}(\mathrm{VI})$ around $\mathrm{pH} 7$ in the presence of $16 \mathrm{CO}_{2}$.

17 (3) The binding of $\mathrm{UO}_{2}{ }^{2+}$ on the layer sites is apparently independent of temperature, 18 whereas the surface complexation reactions on edge sites are endothermic. The $19 \Delta_{r} H_{m}^{\theta}$ of surface complexation reactions of $\mathrm{UO}_{2}{ }^{+},\left(\mathrm{UO}_{2}\right)_{3}(\mathrm{OH})_{5}{ }^{+}$, and $\left(\mathrm{UO}_{2}\right)_{3}(\mathrm{OH})_{7}{ }^{-}$ 20 on the edge sites are 52,158 , and $188 \mathrm{~kJ} / \mathrm{mol}$, respectively. 


\section{Acknowledgments}

The financial support by the National Natural Science Foundation of China (No. 20971061) is gratefully appreciated.

\section{References}

1. McKinley, J.P., Zachara, J.M., Smith, S.C., Turner, G.D.: The influence of uranyl hydrolysis and multiple site-binding reactions on adsorption of U(VI) to montmorillonite. Clays Clay Miner. 43, 586 (1995).

2. Turner, G.D., Zachara, J.M., McKinley, J.P., Smith, S.C.: Surface-charge properties and $\mathrm{UO}_{2}{ }^{2+}$ adsorption of a subsurface smectite. Geochim. Cosmochim. Acta 60, 3399 (1996).

3. Pabalan, R.T., Turner, D.R.: Uranium (6+) sorption on montmorillonite: Experimental and surface complexation modeling study. Aquat. Geochem. 2, 203 (1997).

4. Chisholm-Brause, C.J., Berg, J.M., Matzner, R.A., Morris, D.E.: Uranium(VI) Sorption Complexes on Montmorillonite as a Function of Solution Chemistry. J. Colloid Interface Sci. 233, 38 (2001).

5. Greathouse, J.A., Cygan, R.T.: Water Structure and Aqueous Uranyl(VI) Adsorption Equilibria onto External Surfaces of Beidellite, Montmorillonite, and Pyrophyllite: Results from Molecular Simulations. Environ. Sci. Technol. 40, 3865 (2006).

6. Kowal-Fouchard, A., Drot, R., Simoni, E., Ehrhardt, J.J.: Use of Spectroscopic Techniques for Uranium(VI)/Montmorillonite Interaction Modeling. Environ. Sci. Technol. 38, 1399(2004).

7. Sylwester, E.R., Hudson, E.A., Allen, P.G.: The structure of uranium(VI) sorption complexes on silica, alumina, and montmorillonite. Geochim. Cosmochim. Acta 64, 2431 (2000).

8. Catalano, J.G., Brown Jr., G.E.: Uranyl adsorption onto montmorillonite : 
Evaluation of binding sites and carbonate complexation, Geochim. Cosmochim. Acta 69, 2995 (2005).

9. Korichia, S., Bensmaili, A.: Sorption of uranium (VI) on homoionic sodium smectite experimental study and surface complexation modeling, J. Hazard. Mater. 169, 780 (2009).

10. Baeyens, B., Bradbury, M.H.: A mechanistic description of Ni and Zn sorption on Na-montmorillonite Part I: Titration and sorption measurements, J. Contam. Hydrol. 27, 199 (1997).

11. Bradbury, M.H., Baeyens, B.: Sorption of Eu on Na- and Ca-montmorillonites: experimental investigations and modelling with cation exchange and surface complexation. Geochim. Cosmochim. Acta 66, 2325 (2002).

12. Kraepiel, A.M.L., Keller, K., Morel, F.M.M.: On the Acid-Base Chemistry of Permanently Charged Minerals, Environ. Sci. Technol. 32, 2829 (1998).

13. Tertre, E., Castet, S., Berger, G., Loubet, M., Giffaut, E.: Geochim. Surface chemistry of kaolinite and Na-montmorillonite in aqueous electrolyte solutions at 25 and $60{ }^{\circ} \mathrm{C}$ : Experimental and modeling study. Geochim. Cosmochim. Acta 70, 4579 (2006).

14. Guo, Z., Xu, J., Shi, K., Tang, Y., Wu, W., Tao, Z.: Eu(III) adsorption/desorption on Na-bentonite: Experimental and modeling studies. Colloids and Surfaces A: Physicochem. Eng. Aspects 339, 126 (2009).

15. Tertre, E., Berger, G., Castet, S., Loubet, M., Giffaut, E.: Experimental sorption of $\mathrm{Ni}^{2+}, \mathrm{Cs}^{+}$and $\mathrm{Ln}^{3+}$ onto a montmorillonite up to $150{ }^{\circ} \mathrm{C}$. Geochim. Cosmochim. Acta 69, 4937 (2005).

16. Tertre, E., Berger, G., Simoni, E., Castet, S., Giffaut, E., Loubet, M., Catalette, H. : Europium retention onto clay minerals from 25 to $150{ }^{\circ} \mathrm{C}$ : Experimental measurements, spectroscopic features and sorption modelling. Geochim. Cosmochim. Acta 70, 4563 (2006).

17. Duc, M., Carteret, C., Thomas, F., Gaboriaud, F.: Temperature effect on the acid-base behavior of Na-montmorillonite. J. Colloid Interface Sci. 327, 472 (2008). 
18. Parkhurst, D.L., Appelo, C.A.J.: User's guide to PHREEQC (Version 2)—a computer program for speciation, batch-reaction, one-dimensional transport, and inverse geochemical calculations, U.S.G.S. Water-Resources Report 99-4259, 1999.

19. Grenthe, I., Fuger, J., Konings, R., Lemire, R.J., Muller, A.B., Nguyen-Trung, C., Wanner, H.: Chemical Thermodynamics of Uranium (H. Wanner and I. Forest, ed.). Nuclear Energy Agency, Organisation for Economic Co-operation and Development, Elsevier, 1992.

20. Hummel, W., Berner, U., Curti, E., Pearson, F.J., Thoenen, T.: Nagra/PSI Chemical Thermodynamic Data Base 01/01. Universal Publishers/uPUBLISH.com USA. Also issued as Nagra Technical Report NTB 02-16, Nagra, Wettingen, Switzerland, 2002.

21. Guo, Z., Li, Y., Wu, W.: Sorption of U(VI) on goethite: Effects of pH, ionic strength, phosphate, carbonate and fulvic acid. Appl. Radiat. Isotopes 67, 996 (2009).

22. Davis, J.A., Meece, D.E., Kohler, M., Curtis, G.P.: Approaches to surface complexation modeling of Uranium(VI) adsorptionon aquifer sediments, Geochim. Cosmochim. Acta 68, 3621 (2004).

23. Waite, T.D., Davis, J.A., Payne, T.E., Waychunas, G.A., Xu, N.: Uranium(VI) adsorption to ferrihydrite: Application of a surface complexation model. Geochim. Cosmochim. Acta 58, 5465 (1994).

24. Lenhart, J.J., Honeyman, B.D.: Uranium(VI) sorption to hematite in the presence of humic acid. Geochim. Cosmochim. Acta 63, 2891 (1999).

25. Montavon, G., Guo, Z., Lützenkirchen, J., Alhajji, E., Kedziorek, M.A.M., Bourg, A.C.M., Grambow, B.: Interaction of selenite with MX-80 bentonite: Effect of minor phases, $\mathrm{pH}$, selenite loading, solution composition and compaction, Colloids and Surfaces A: Physicochem. Eng. Aspects 332, 71 (2009). 
Table 1. Modeling parameters for the acid-base chemistry of the Na-bentonite [14].

\begin{tabular}{ll} 
Description of the purified Na-bentonite & \\
\hline Specific surface area & $53.6 \mathrm{~m}^{2} / \mathrm{g}$ \\
\hline Sites & Site density \\
\hline $\mathrm{X}^{-}$ & $1.16 \times 10^{-5} \mathrm{~mol} / \mathrm{m}^{2} \quad(623 \mathrm{meq} / \mathrm{kg})$ \\
$\equiv \mathrm{SOH}$ & $5.88 \times 10^{-7} \mathrm{~mol} / \mathrm{m}^{2}$ \\
$\equiv \mathrm{YOH}$ & $1.18 \times 10^{-6} \mathrm{~mol} / \mathrm{m}^{2}$ \\
\hline Aqueous solution/solid equilibria: Reactions involved in acid-base titration \\
\hline $\mathrm{Reactions}$ & $\log \mathrm{K}^{\text {int }}(T=298 \mathrm{~K})$ \\
\hline $\mathrm{XNa} \rightleftharpoons \mathrm{X}^{-}+\mathrm{Na}^{+}$ & -1.3 \\
$\mathrm{XNa}+\mathrm{H}^{+} \rightleftharpoons \mathrm{XH}^{+} \mathrm{Na}^{+}$ & 0.79 \\
$\equiv \mathrm{SOH}+\mathrm{H}^{+} \rightleftharpoons \mathrm{SOH}_{2}^{+}$ & 3.23 \\
$\equiv \mathrm{SOH} \rightleftharpoons \mathrm{SO}^{-}+\mathrm{H}^{+}$ & -3.89 \\
$\equiv \mathrm{YOH} \rightleftharpoons \mathrm{YO}^{-}+\mathrm{H}^{+}$ & -6.57
\end{tabular}


Table 2. Thermodynamic data for aqueous reactions of U(VI) used in modeling $(I=0$, $T=298.15 \mathrm{~K})[19,20]$.

\begin{tabular}{|c|c|c|}
\hline Reactions & $\log K$ & $\begin{array}{c}\Delta_{r} H_{m}^{o} \\
(\mathrm{~kJ} / \mathrm{mol})\end{array}$ \\
\hline $\mathrm{UO}_{2}^{2+}+\mathrm{H}_{2} \mathrm{O} \rightleftharpoons \mathrm{UO}_{2} \mathrm{OH}^{+}+\mathrm{H}^{+}$ & -5.20 & 58 \\
\hline $\mathrm{UO}_{2}^{2+}+2 \mathrm{H}_{2} \mathrm{O} \rightleftharpoons \mathrm{UO}_{2}(\mathrm{OH})_{2}(\mathrm{aq})+2 \mathrm{H}^{+}$ & -12.0 & 20 \\
\hline $\mathrm{UO}_{2}^{2+}+3 \mathrm{H}_{2} \mathrm{O} \rightleftharpoons \mathrm{UO}_{2}(\mathrm{OH})_{3}^{-}+3 \mathrm{H}^{+}$ & -19.2 & - \\
\hline $\mathrm{UO}_{2}^{2+}+4 \mathrm{H}_{2} \mathrm{O} \rightleftharpoons \mathrm{UO}_{2}(\mathrm{OH})_{4}^{2-}+4 \mathrm{H}^{+}$ & -33.0 & - \\
\hline $2 \mathrm{UO}_{2}^{2+}+\mathrm{H}_{2} \mathrm{O} \rightleftharpoons\left(\mathrm{UO}_{2}\right)_{2} \mathrm{OH}^{3+}+\mathrm{H}^{+}$ & -2.70 & - \\
\hline $2 \mathrm{UO}_{2}{ }^{2+}+2 \mathrm{H}_{2} \mathrm{O} \rightleftharpoons\left(\mathrm{UO}_{2}\right)_{2}(\mathrm{OH})_{2}{ }^{2+}+2 \mathrm{H}^{+}$ & -5.62 & 54 \\
\hline $3 \mathrm{UO}_{2}{ }^{2+}+4 \mathrm{H}_{2} \mathrm{O} \rightleftharpoons\left(\mathrm{UO}_{2}\right)_{3}(\mathrm{OH})_{4}{ }^{2+}+4 \mathrm{H}^{+}$ & -11.9 & - \\
\hline $3 \mathrm{UO}_{2}{ }^{2+}+5 \mathrm{H}_{2} \mathrm{O} \rightleftharpoons\left(\mathrm{UO}_{2}\right)_{3}(\mathrm{OH})_{5}^{+}+5 \mathrm{H}^{+}$ & -15.55 & 105 \\
\hline $3 \mathrm{UO}_{2}^{2+}+7 \mathrm{H}_{2} \mathrm{O} \rightleftharpoons\left(\mathrm{UO}_{2}\right)_{3}(\mathrm{OH})_{7}^{-}+7 \mathrm{H}^{+}$ & -31.0 & - \\
\hline $4 \mathrm{UO}_{2}{ }^{2+}+7 \mathrm{H}_{2} \mathrm{O} \rightleftharpoons\left(\mathrm{UO}_{2}\right)_{4}(\mathrm{OH})_{7}^{+}+7 \mathrm{H}^{+}$ & -21.9 & - \\
\hline $\mathrm{UO}_{2}^{2+}+\mathrm{CO}_{3}^{2-} \rightleftharpoons \mathrm{UO}_{2} \mathrm{CO}_{3}(\mathrm{aq})$ & 9.68 & 5.0 \\
\hline $\mathrm{UO}_{2}^{2+}+2 \mathrm{CO}_{3}^{2-} \rightleftharpoons \mathrm{UO}_{2}\left(\mathrm{CO}_{3}\right)_{2}^{2-}$ & 16.94 & 18.5 \\
\hline $\mathrm{UO}_{2}^{2+}+3 \mathrm{CO}_{3}^{2-} \rightleftharpoons \mathrm{UO}_{2}\left(\mathrm{CO}_{3}\right)_{3}^{4-}$ & 21.60 & -39.2 \\
\hline $3 \mathrm{UO}_{2}^{2+}+6 \mathrm{CO}_{3}^{2-} \rightleftharpoons\left(\mathrm{UO}_{2}\right)_{3}\left(\mathrm{CO}_{3}\right)_{6}^{6-}$ & 54.00 & -62.7 \\
\hline $2 \mathrm{UO}_{2}{ }^{2+}+\mathrm{CO}_{2}(\mathrm{~g})+4 \mathrm{H}_{2} \mathrm{O}(\mathrm{l}) \rightleftharpoons\left(\mathrm{UO}_{2}\right)_{2} \mathrm{CO}_{3}(\mathrm{OH})_{3}^{-}+5 \mathrm{H}^{+}$ & -19.01 & - \\
\hline $3 \mathrm{UO}_{2}^{2+}+\mathrm{CO}_{2}(\mathrm{~g})+4 \mathrm{H}_{2} \mathrm{O}(\mathrm{l}) \rightleftharpoons\left(\mathrm{UO}_{2}\right)_{3} \mathrm{O}(\mathrm{OH})_{2}\left(\mathrm{HCO}_{3}\right)^{+}+5 \mathrm{H}^{+}$ & -17.5 & - \\
\hline $11 \mathrm{UO}_{2}^{2+}+6 \mathrm{CO}_{2}(\mathrm{~g})+18 \mathrm{H}_{2} \mathrm{O}(\mathrm{l}) \rightleftharpoons\left(\mathrm{UO}_{2}\right)_{11}\left(\mathrm{CO}_{3}\right)_{6}(\mathrm{OH})_{12}^{2-}+24 \mathrm{H}^{+}$ & -72.5 & - \\
\hline $\mathrm{UO}_{2}^{2+}+\mathrm{Cl}^{-} \rightleftharpoons \mathrm{UO}_{2} \mathrm{Cl}^{+}$ & 0.17 & 8.0 \\
\hline $\mathrm{UO}_{2}^{2+}+2 \mathrm{Cl}^{-} \rightleftharpoons \mathrm{UO}_{2} \mathrm{Cl}_{2}(\mathrm{aq})$ & -1.10 & 15 \\
\hline
\end{tabular}


Table 3. Surface complexation reactions of U(VI) on Na-bentonite and corresponding intrinsic equilibrium constants $(I=0 \mathrm{~mol} / \mathrm{L})$.

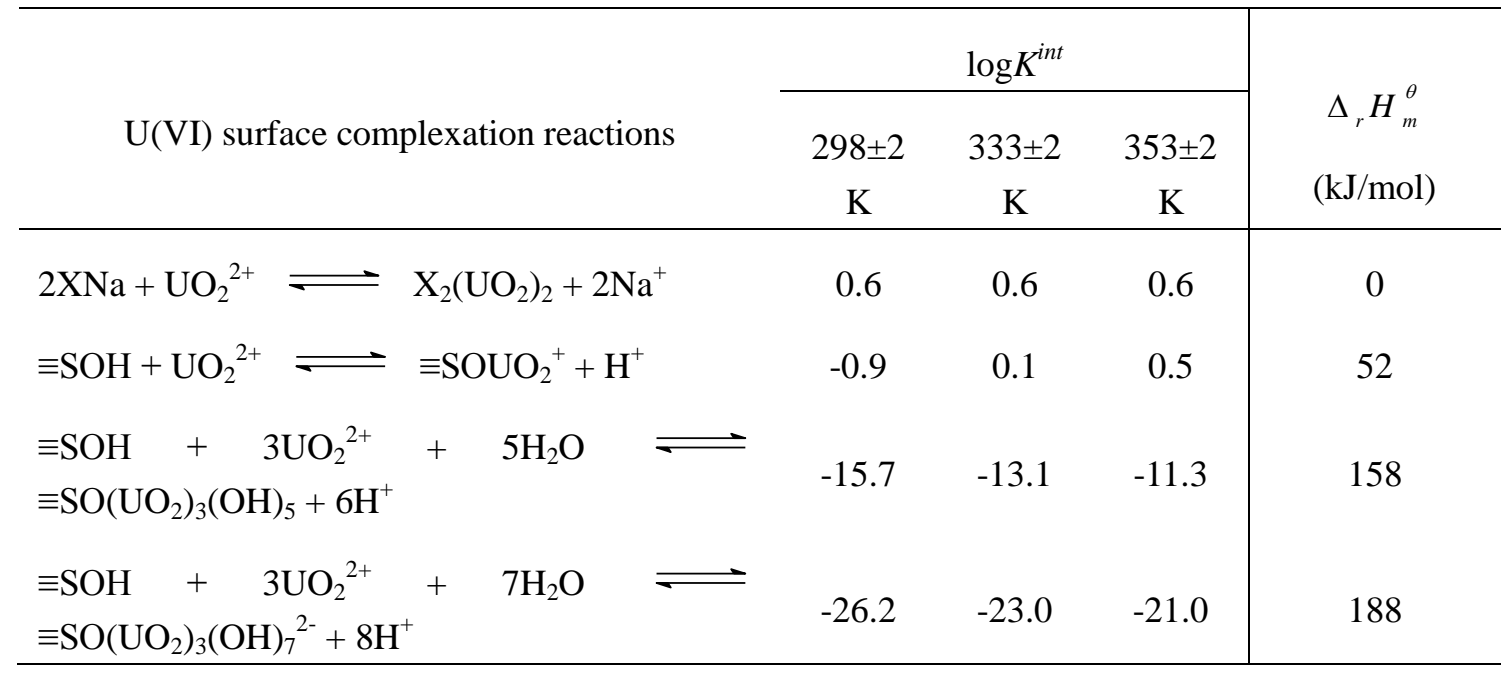




\section{Figure Captions}

Fig. 1. Sorption curves of $\mathrm{U}(\mathrm{VI})$ versus $\mathrm{pH}$ on the Na-bentonite at different initial U(VI) concentrations; $T=298 \pm 2 \mathrm{~K}, I=0.1 \mathrm{~mol} / \mathrm{L} \mathrm{NaCl}$ and $m / V=1 \mathrm{~g} / \mathrm{L}$. The points show the experimental data and the solid lines represent the results calculated by the proposed model. The dash lines illustrate the contributions of different surface complexes to U(VI) sorption at $C_{U(V I)}^{0}=8.02 \times 10^{-5} \mathrm{~mol} / \mathrm{L}$ : (A) $\mathrm{X}_{2} \mathrm{UO}_{2} ;(\mathrm{B}) \equiv \mathrm{SOUO}_{2}{ }^{+} ;(\mathrm{C}) \equiv \mathrm{SO}\left(\mathrm{UO}_{2}\right)_{3}(\mathrm{OH})_{5} ;(\mathrm{D}) \equiv \mathrm{SO}\left(\mathrm{UO}_{2}\right)_{3}(\mathrm{OH})_{7}{ }^{2-}$.

Fig. 2. Speciation of U(VI) in NaCl solution; $T=298.15 \mathrm{~K}, C_{U(V I)}^{0}=4.0 \times 10^{-5} \mathrm{~mol} / \mathrm{L}$ and $I=0.1 \mathrm{~mol} / \mathrm{L} \mathrm{NaCl}$; (a) $P_{\mathrm{CO}_{2}}=0$; (b) $P_{\mathrm{CO}_{2}}=10^{-3.58}$ atm; Solids are not allowed to precipitate.

Fig. 3. Sorption isotherms of U(VI) on the Na-bentonite; $T=298 \pm 2 \mathrm{~K}, I=0.1 \mathrm{~mol} / \mathrm{L}$ $\mathrm{NaCl}$ and $m / V=1 \mathrm{~g} / \mathrm{L}$. The points show the experimental data and the lines represent the results calculated by the proposed model.

Fig. 4. Effect of $m / V$ upon $\mathrm{U}(\mathrm{VI})$ sorption on the Na-bentonite; $T=298 \pm 2 \mathrm{~K}, C_{\mathrm{U}(\mathrm{VI})}^{0}$ $=8.02 \times 10^{-5} \mathrm{~mol} / \mathrm{L}, \mathrm{pH}=5.00 \pm 0.10$ and $I=0.1 \mathrm{~mol} / \mathrm{L} \mathrm{NaCl}$. The points show the experimental data and the line represents the results calculated by the proposed model.

Fig. 5. Sorption curves of U(VI) versus $\mathrm{pH}$ on the Na-bentonite in the presence and absence of $\mathrm{CO}_{2} ; T=298 \pm 2 \mathrm{~K}, C_{\mathrm{U}(\mathrm{VI})}^{0}=8.02 \times 10^{-5} \mathrm{~mol} / \mathrm{L}, I=0.1 \mathrm{~mol} / \mathrm{L} \mathrm{NaCl}$ and $m / V=1 \mathrm{~g} / \mathrm{L}$. The points show the experimental data, the solid line represents the results calculated by the proposed model for the sorption system at $P_{\mathrm{CO}_{2}}=10^{-3.58} \mathrm{~atm}$. The dash lines illustrate the contributions of different surface complexes to $\mathrm{U}(\mathrm{VI})$ sorption at $P_{\mathrm{CO}_{2}}=10^{-3.58}$ atm: (A) $\mathrm{X}_{2} \mathrm{UO}_{2}$; (B) $\equiv \mathrm{SOUO}_{2}{ }^{+} ;(\mathrm{C}) \equiv \mathrm{SO}\left(\mathrm{UO}_{2}\right)_{3}(\mathrm{OH})_{5} ;(\mathrm{D}) \equiv \mathrm{SO}\left(\mathrm{UO}_{2}\right)_{3}(\mathrm{OH})_{7}{ }^{2-}$.

Fig. 6. Sorption curves of U(VI) versus $\mathrm{pH}$ on the Na-bentonite at different 
temperatures; $C_{\mathrm{U}(\mathrm{VI})}^{0}=8.02 \times 10^{-5} \mathrm{~mol} / \mathrm{L}, I=0.1 \mathrm{~mol} / \mathrm{L} \mathrm{NaCl}, m / V=1 \mathrm{~g} / \mathrm{L}$. The points show the experimental data and the lines represent the results calculated by the proposed model with the equilibrium constants listed in Table 3.

Fig. 7. The dependence of equilibrium constants $\left(K^{\mathrm{int}}\right)$ of $\mathrm{U}(\mathrm{VI})$ surface complexation reactions on temperature according to the van't Hoff equation; (a) $\equiv \mathrm{SOUO}_{2}{ }^{+}$; (b) $\equiv \mathrm{SO}\left(\mathrm{UO}_{2}\right)_{3}(\mathrm{OH})_{5} ;(\mathrm{c}) \equiv \mathrm{SO}\left(\mathrm{UO}_{2}\right)_{3}(\mathrm{OH})_{7}{ }^{2-}$. 


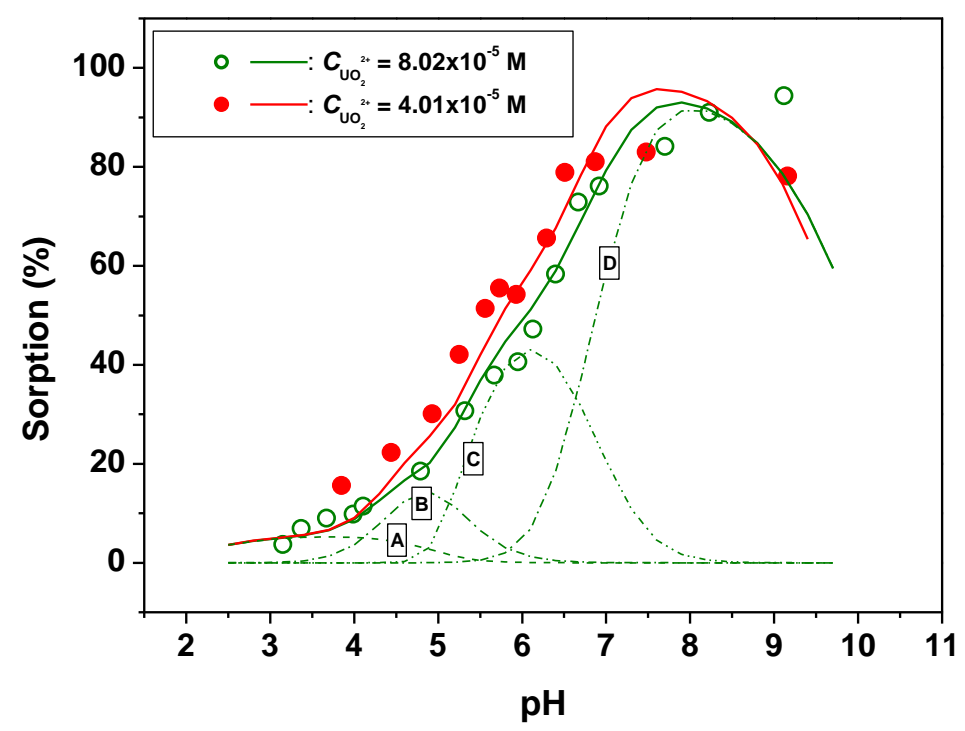

Fig. 1. Sorption curves of $\mathrm{U}(\mathrm{VI})$ versus $\mathrm{pH}$ on the Na-bentonite at different initial U(VI) concentrations; $T=298 \pm 2 \mathrm{~K}, I=0.1 \mathrm{~mol} / \mathrm{L} \mathrm{NaCl}$ and $m / V=1 \mathrm{~g} / \mathrm{L}$. The points show the experimental data and the solid lines represent the results calculated by the proposed model. The dash lines illustrate the contributions of different surface complexes to U(VI) sorption at $C_{U(V I)}^{0}=8.02 \times 10^{-5} \mathrm{~mol} / \mathrm{L}$ : (A) $\mathrm{X}_{2} \mathrm{UO}_{2} ;(\mathrm{B}) \equiv \mathrm{SOUO}_{2}{ }^{+}$; $(\mathrm{C}) \equiv \mathrm{SO}\left(\mathrm{UO}_{2}\right)_{3}(\mathrm{OH})_{5} ;(\mathrm{D}) \equiv \mathrm{SO}\left(\mathrm{UO}_{2}\right)_{3}(\mathrm{OH})_{7}{ }^{2-}$. 

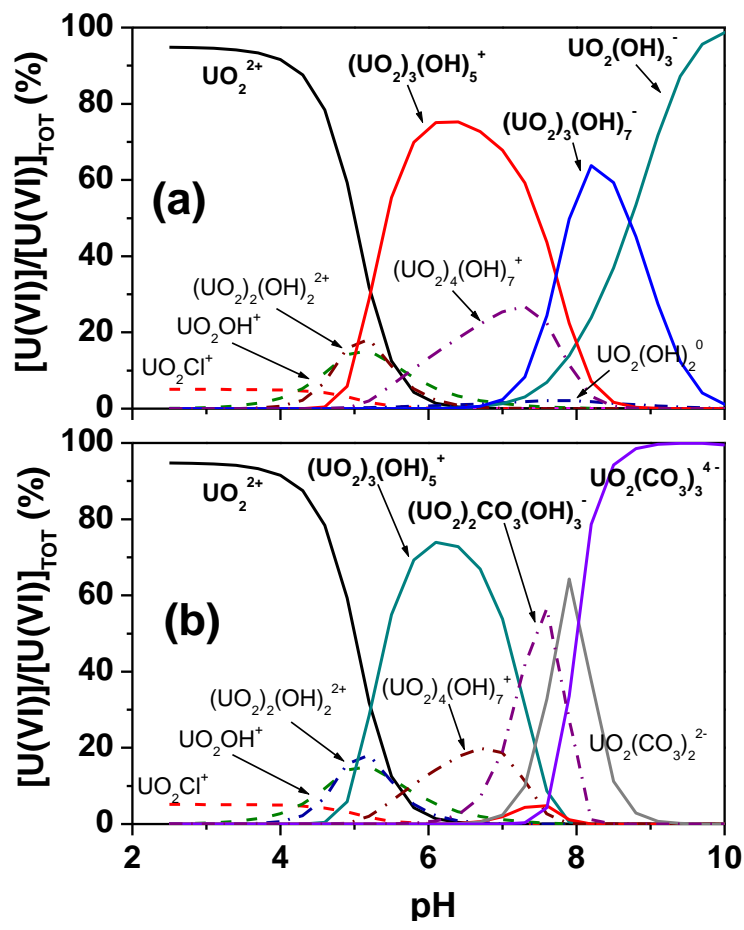

Fig. 2. Speciation of $\mathrm{U}(\mathrm{VI})$ in $\mathrm{NaCl}$ solution; $T=298.15 \mathrm{~K}, C_{U(V I)}^{0}=4.0 \times 10^{-5} \mathrm{~mol} / \mathrm{L}$ and $I=0.1 \mathrm{~mol} / \mathrm{L} \mathrm{NaCl}$; (a) $P_{\mathrm{CO}_{2}}=0$; (b) $P_{\mathrm{CO}_{2}}=10^{-3.58}$ atm; Solids are not allowed to precipitate. 


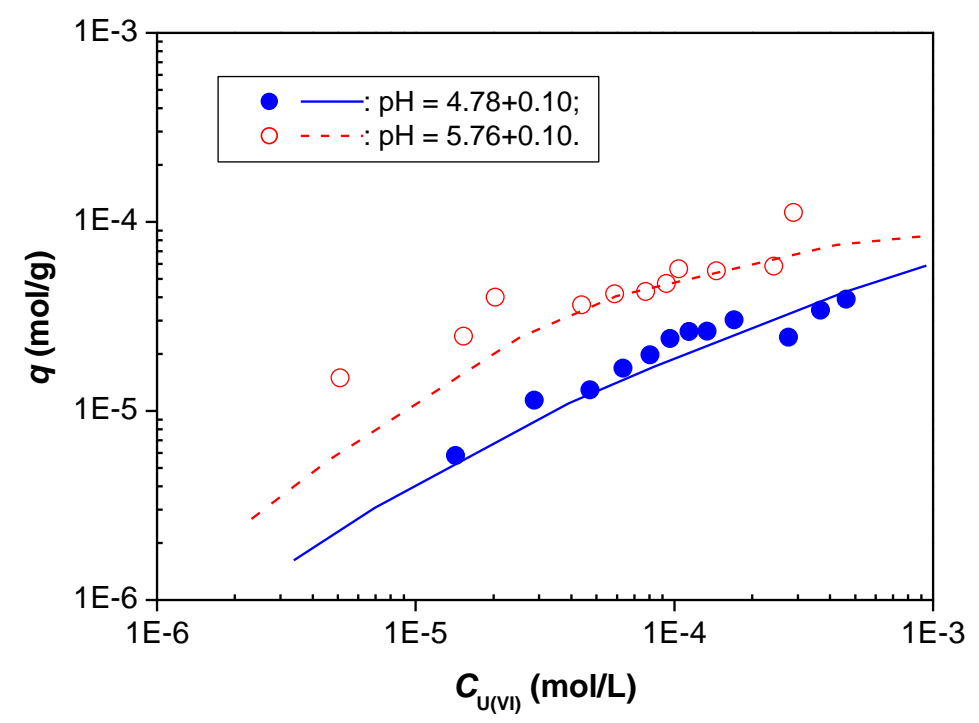

Fig. 3. Sorption isotherms of U(VI) on the Na-bentonite; $T=298 \pm 2 \mathrm{~K}, I=0.1 \mathrm{~mol} / \mathrm{L}$ $\mathrm{NaCl}$ and $m / V=1 \mathrm{~g} / \mathrm{L}$. The points show the experimental data and the lines represent the results calculated by the proposed model. 


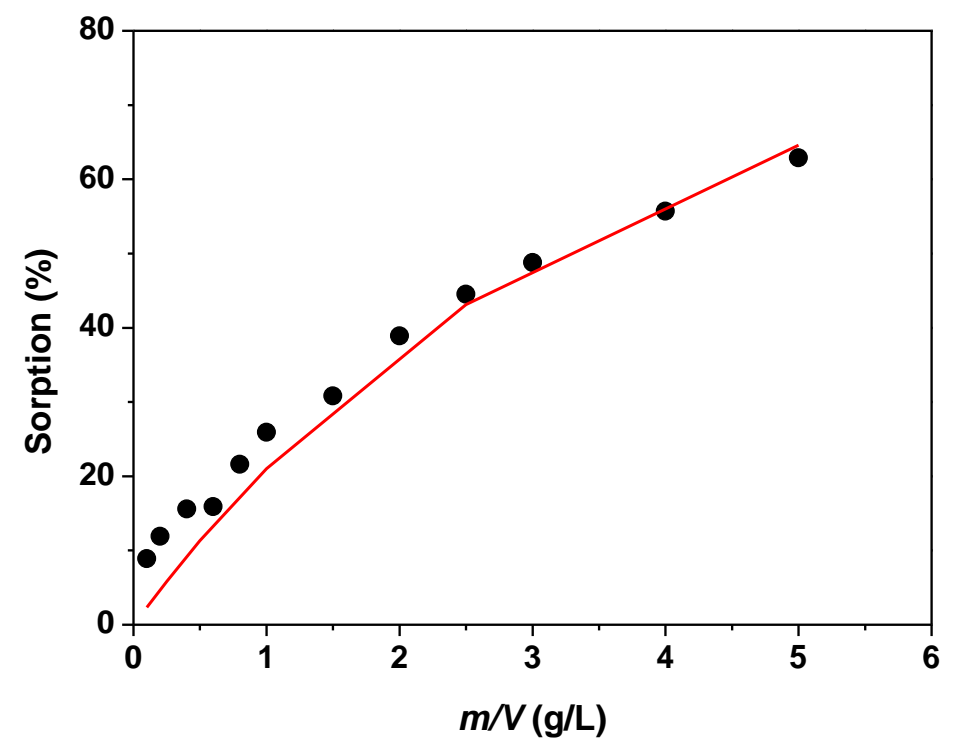

Fig. 4. Effect of $m / V$ upon $\mathrm{U}(\mathrm{VI})$ sorption on the Na-bentonite; $T=298 \pm 2 \mathrm{~K}, C_{\mathrm{U}(\mathrm{VI})}^{0}$ $=8.02 \times 10^{-5} \mathrm{~mol} / \mathrm{L}, \mathrm{pH}=5.00 \pm 0.10$ and $I=0.1 \mathrm{~mol} / \mathrm{L} \mathrm{NaCl}$. The points show the experimental data and the line represents the results calculated by the proposed model. 


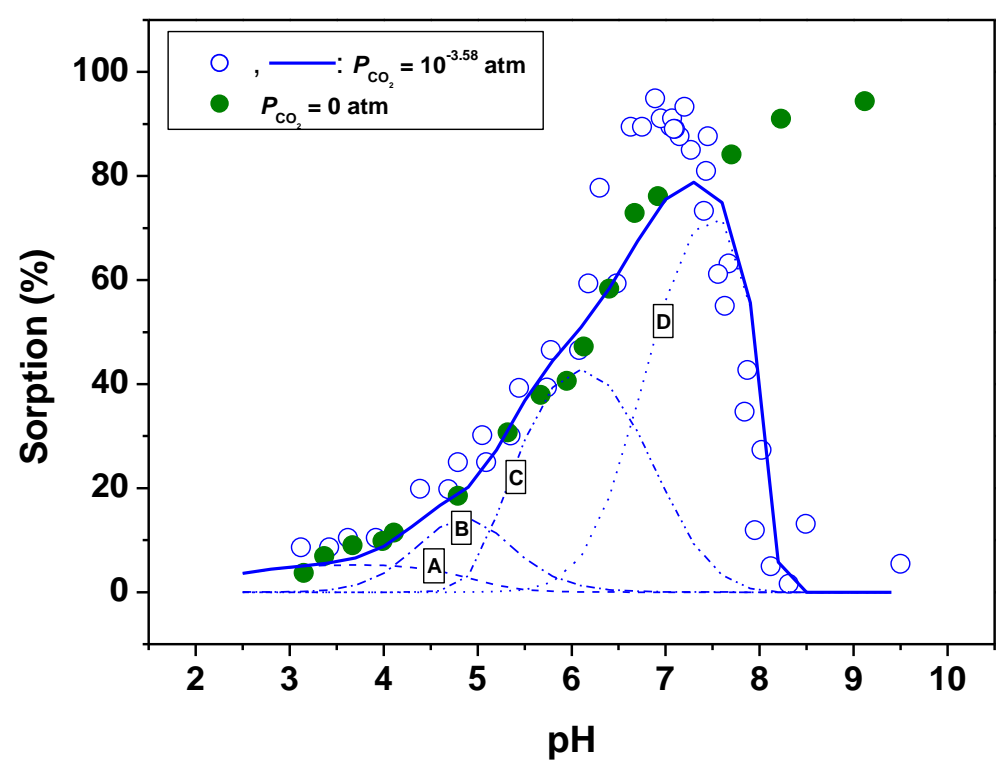

Fig. 5. Sorption curves of U(VI) versus $\mathrm{pH}$ on the Na-bentonite in the presence and absence of $\mathrm{CO}_{2} ; T=298 \pm 2 \mathrm{~K}, C_{\mathrm{U}(\mathrm{VI})}^{0}=8.02 \times 10^{-5} \mathrm{~mol} / \mathrm{L}, I=0.1 \mathrm{~mol} / \mathrm{L} \mathrm{NaCl}$ and $m / V=1 \mathrm{~g} / \mathrm{L}$. The points show the experimental data, the solid line represents the results calculated by the proposed model for the sorption system at $P_{\mathrm{CO}_{2}}=10^{-3.58} \mathrm{~atm}$. The dash lines illustrate the contributions of different surface complexes to U(VI) sorption at $P_{\mathrm{CO}_{2}}=10^{-3.58}$ atm: (A) $\mathrm{X}_{2} \mathrm{UO}_{2} ;(\mathrm{B}) \equiv \mathrm{SOUO}_{2}{ }^{+} ;(\mathrm{C}) \equiv \mathrm{SO}\left(\mathrm{UO}_{2}\right)_{3}(\mathrm{OH})_{5} ;(\mathrm{D})$ $\equiv \mathrm{SO}\left(\mathrm{UO}_{2}\right)_{3}(\mathrm{OH})_{7}{ }^{2-}$. 


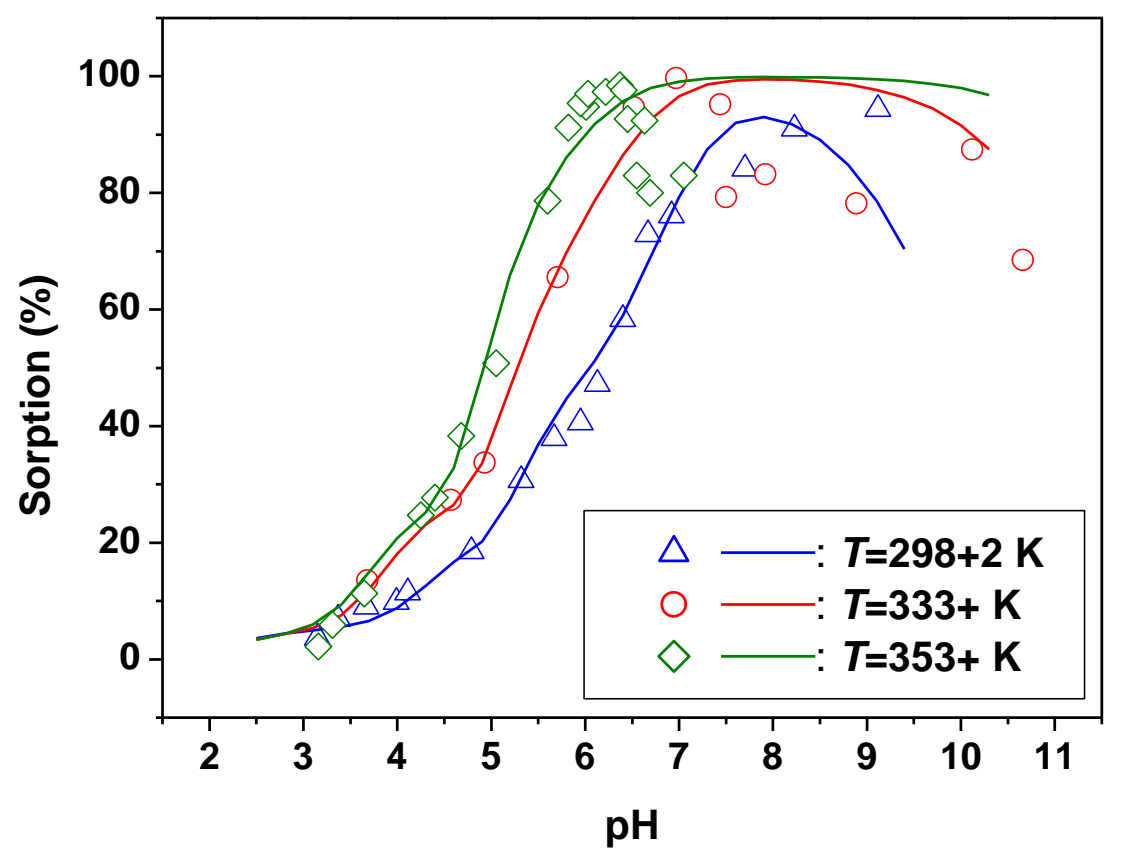

Fig. 6. Sorption curves of U(VI) versus $\mathrm{pH}$ on the Na-bentonite at different temperatures; $C_{\mathrm{U}(\mathrm{VI})}^{0}=8.02 \times 10^{-5} \mathrm{~mol} / \mathrm{L}, I=0.1 \mathrm{~mol} / \mathrm{L} \mathrm{NaCl}, m / V=1 \mathrm{~g} / \mathrm{L}$. The points show the experimental data and the lines represent the results calculated by the proposed model with the equilibrium constants listed in Table 3. 


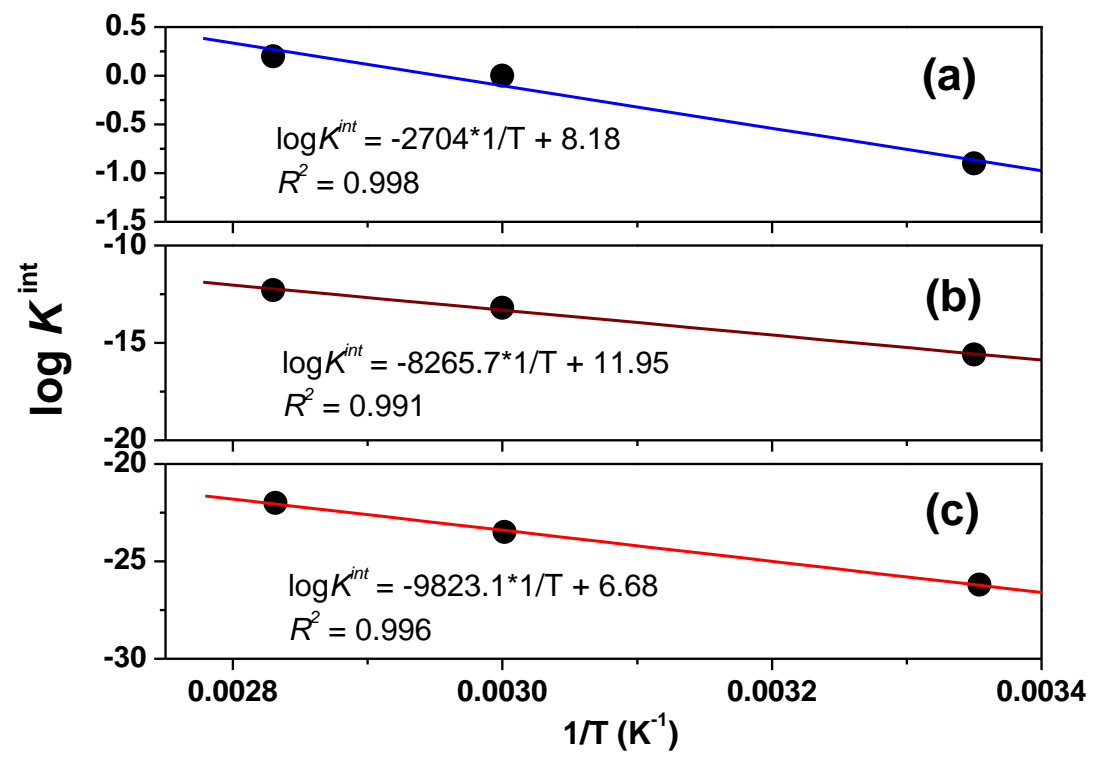

Fig. 7. The dependence of equilibrium constants $\left(K^{\mathrm{int}}\right)$ of U(VI) surface complexation reactions on temperature according to the van't Hoff equation; (a) $\equiv \mathrm{SOUO}_{2}{ }^{+}$; (b) $\equiv \mathrm{SO}\left(\mathrm{UO}_{2}\right)_{3}(\mathrm{OH})_{5} ;(\mathrm{c}) \equiv \mathrm{SO}\left(\mathrm{UO}_{2}\right)_{3}(\mathrm{OH})_{7}{ }^{2-}$. 